\title{
A HISTÓRIA DA DUPLA HÉLICE DO DNA NOS LIVROS DIDÁTICOS: SUAS POTENCIALIDADES E UMA PROPOSTA DE DIÁLOGO
}

\author{
The history of the DNA double helix in textbooks: \\ potentialities and a proposal for a dialogue
}

\author{
Marcos Rodrigues da Silva ${ }^{1}$. Marinez Meneghello Passos ${ }^{2}$. \\ Anderson Vilas Boas ${ }^{3}$
}

Resumo: Mediante a análise de sete dos nove títulos de livros didáticos qualificados pelo Programa do Livro para o Ensino Médio (PNLEM/2009), procurou-se mostrar que há uma concepção de ciência intrínseca a cada uma das propostas apresentadas nesses livros. Entre os referenciais assumidos para o desenvolvimento da análise, está a inserção de história mediante o aporte filosófico de uma abordagem relacional, que leva em consideração - quando se narra a história de um conceito científico - a relação entre este conceito e o problema a partir do qual emerge a necessidade deste conceito. Esta investigação levou-nos à conclusão de que os elementos históricos contidos nos livros didáticos, referentes à história da dupla hélice do DNA, possibilitam a constituição de uma concepção de ciências que mostra a ciência como uma construção histórica, pela razão de que seus resultados são respostas a problemas legitimados historicamente.

Palavras-chave: Ensino de biologia. Ensino Médio. Livro didático. Dupla hélice do DNA.

\begin{abstract}
Based on the analysis of seven books from the nine titles of textbooks qualified by the The High School Book Program (PNLEM /2009), an attempt has been made to show that there is an intrinsic conception of science in each proposal presented in those books. Among the references assumed in the development of the analysis is the insertion of history by the philosophical use of a relational approach which considers, when the history of a scientific concept is narrated, the relationship between this concept and the problem, and based on this, the need for such concept emerges. This investigation has brought us to the conclusion that the historical elements contained in the textbooks, referring to the history of the DNA double helix, make it possible for the constitution of a conception of sciences that shows science as a historical construction because its results are answers to historically legitimized problems.
\end{abstract}

Keywords: Biology teaching. High school. Textbook. DNA double helix.

\footnotetext{
${ }^{1}$ Universidade Estadual de Londrina (UEL), Centro de Letras e Ciências Humanas, Departamento de Filosofia, Rodovia Celso Garcia, Cid. Bandeirantes, Londrina, CEP 86055-900, PR, Brasil. E-mail: mrs.marcos@uel.br

${ }^{2}$ Universidade Estadual de Londrina (UEL), Centro de Ciências Exatas, Departamento de Matemática, Londrina, PR, Brasil.

${ }^{3}$ Universidade Federal de Alagoas (UFAL), Instituto de Física. Maceió, AL, Brasil.
} 
Silva, M. R.; Passos, M. M.; Villas Boas, A.

\section{Introdução}

Ao se buscarem informações sobre investigações que possuem o livro didático de biologia do Ensino Médio como objeto de estudo, verifica-se que os objetivos de pesquisa dos que se debruçam sobre esses livros são deveras variados.

Há aqueles que procuram compreensões sobre o papel do livro didático, sua utilização didática e sua avaliação (MEGID NETO; FRACALANZA, 2003, p. 147-148); existem os que se propõem a analisar de forma comparativa o livro didático de biologia e a utilização de apostilas (SANTOS et al., 2007); aqueles que procuram evidenciar a concepção de história da biologia veiculada nos livros didáticos (CARNEIRO; GASTAL, 2005); os que se dedicam a conteúdos específicos, como: serpentes peçonhentas e acidentes ofídicos (SANDRIN; PUORTO; NARDI, 2005), ciclo de nitrogênio (CAMPOS; LIMA, 2008), genética e biologia molecular (MELO; CARMO, 2009) e educação ambiental (MARPICA; LOGAREZZI, 2010), presentes nesses manuais.

Contudo, as discussões e considerações a que diversos desses pesquisadores nos remetem trazem à tona um quadro avaliativo nada otimista para os livros didáticos de biologia do Ensino Médio.

$\mathrm{Na}$ sequência, relacionamos algumas dessas conclusões e, pautados nesses assinalamentos, justificamos nosso movimento e os resultados que aqui trazemos.

Os resultados sugerem que os atuais livros didáticos não estão atualizados no estudo dos temas considerados essenciais para perfeito entendimento e aquisição de informações associadas ao rápido avanço do conhecimento na área da Nova Biologia. Aponta-se para o fato de que necessitam de reformulação e atualizações com textos modernos, que promovam mudanças conceituais. (XAVIER; FREIRE; MORAES, 2006, p. 275)

Apesar de todos os esforços empreendidos até o momento, ainda não se alterou o tratamento dado ao conteúdo presente no livro que configura erroneamente o conhecimento científico como um produto acabado, elaborado por mentes privilegiadas, desprovidas de interesses político-econômicos e ideológicos, ou seja, que apresenta o conhecimento sempre como verdade absoluta, desvinculado do contexto histórico e sociocultural. (MEGID NETO; FRACALANZA, 2003, p. 151)

Ao analisar este material curricular foi possível observar que a história apresentada é desvinculada do contexto cultural de cada período histórico, o que pode levar o aluno a construir uma falsa representação da ciência e do fazer científico. (CARNEIRO; GASTAL, 2005, p. 33)

Verificou-se que todos os materiais didáticos analisados apresentam falhas. No entanto, em uma das apostilas, foram encontradas mais falhas, pois além do seu conteúdo ser extremamente sucinto e não apre- 
A história da dupla hélice do DNA ...

sentar um planejamento em relação às atividades propostas [...]. (SAN-

TOS et al., 2007, p. 311)

No entanto, verificamos que o conjunto dessas pesquisas apresenta lacunas em sua potencial contribuição para a melhoria dos livros didáticos como ferramenta que propicie a incorporação da dimensão ambiental no processo de ensino e aprendizagem. (MARPICA; LOGAREZZI, 2010, p. 115)

Embora compatíveis em quantidade, os artigos das categorias ALD (análise de livro didático), HIS (histórico) e PRC (propostas curriculares) encontram-se publicados em pouquíssima quantidade no que se refere às pesquisas relacionadas ao ensino de Genética e Biologia Molecular na escola básica brasileira, sobretudo no Ensino Médio, que é o foco deste trabalho. (MELO; CARMO, 2009, p. 602)

Como foi possível verificar nesses fragmentos de artigos, a situação do livro didático de biologia provoca desconforto tanto para a comunidade dos que o avaliam quanto para aqueles que o idealizam.

Sabe-se que são bastante difundidas as concepções de que: i) é importante a inserção de história da ciência no ensino de ciências, e ii) quando verificada, a inserção de história no ensino de ciências, em livros didáticos, incorre em uma série de erros.

Em um caso específico a ser investigado neste artigo - a história da dupla hélice do $\mathrm{DNA}^{4}$ - verificamos, porém, que tanto a história é inserida quanto o é de forma correta do ponto de vista informativo.

Entretanto, tal história, do modo como está inserida, sugere certa concepção de ciências que poderia ser assim expressa: a ciência é uma construção histórica tornada possível pela soma das realizações científicas relacionadas com o episódio que está sendo narrado.

Diante dessas colocações, pretendemos mostrar que os elementos históricos contidos nos livros didáticos possibilitam, no entanto, a constituição de outra concepção de ciências (que não a indicada no parágrafo anterior): uma concepção que mostra a ciência como construção histórica, não pelo fato de ser uma soma de produções mapeáveis historiograficamente, mas pela razão de que seus resultados são respostas a problemas legitimados historicamente.

Neste sentido, a menção a esses problemas, no momento de narrar certas realizações científicas, poderia ser de grande utilidade para a constituição dessa possível concepção de ciências.

A fim de verificarmos que tipo de concepção de ciências é esta de que estamos falando, apresentaremos na próxima seção, de forma resumida, alguns referenciais teórico-filosóficos que podem ser úteis para esta tarefa de verificação.

${ }^{4}$ No ano de 2013, comemoram-se os sessenta anos da história da dupla hélice do DNA. 
Silva, M. R.; Passos, M. M.; Villas Boas, A.

\section{Referenciais teóricos e a construção interpretativa}

Nesta seção - fragmentada em subseções - são apresentadas posições filosóficas que nos auxiliam a compreender a relação entre os problemas científicos e suas respostas através das realizações científicas. Sintetizando tais posições, chegamos a uma concepção (filosófica) que denominaremos de relacional - A filosofia da ciência em um enfoque relacional.

$\mathrm{Na}$ continuidade, trazemos um extrato da história da construção do modelo - Um aspecto da história da dupla hélice em uma concepção relacional; na sequência, destacamos dois pontos de inflexão desta história - Dois aspectos históricos da construção do modelo da dupla hélice; e, fechando a seção, enfatizamos, por meio de uma concepção relacional, estes pontos de inflexão - A dupla hélice em um enfoque relacional.

Cabe enfatizar, neste momento, que o objetivo deste artigo não é o de criticar os livros didáticos em sua apresentação da história da ciência, mas, sim, promover um diálogo a fim de se buscar explorar as potencialidades historiográficas destes manuais, isto é, pretendemos mostrar, a princípio, que há uma concepção de ciências intrínseca às propostas apresentadas nesses manuais, e, em específico, trazemos, para tal construção analítica, a história da dupla hélice do DNA.

Em um segundo movimento (na continuidade do artigo), apresentamos nossas proposições a respeito do que se poderia projetar diante dessas evidências.

\section{A filosofia da ciência em um enfoque relacional}

Supondo que admitamos a importância da inserção de história da ciência nos conteúdos, resta-nos saber que tipo de inserção poderia ser feito.

Nossa opção aqui é a inserção de história mediante o aporte filosófico de uma abordagem relacional, que poderia ser assim caracterizada: uma abordagem que leva em consideração, quando se narra a história de um conceito científico, a relação entre este conceito e o problema a partir do qual emerge a necessidade deste conceito no interior de uma ciência.

Deste modo, em uma abordagem relacional, não é possível, simplesmente, mencionar alguns detalhes históricos de um conceito (por exemplo, o nome do cientista associado a este conceito), ela precisa ser extraída de concepções filosófico-historiográficas de ciência 5 .

O primeiro teórico a contribuir para esta concepção foi Thomas Kuhn. De acordo com ele, conceitos científicos possuem uma história; esta história - acrescenta - é uma história que ocorre no interior de um programa científico de investigação conduzido por uma comunidade de investigadores - programa este denominado de paradigma. Esta condução, por sua vez, não ocorre mediante o uso de regras determinadas. Um claro exemplo disto é o conceito de gravidade, conforme apresentado por Newton (KUHN, 1975, p. 139-140).

Para Kuhn (1975), o conceito de gravidade padecia do mesmo defeito (apontado pelos modernos) de conceitos da física aristotélica: a gravidade seria uma qualidade oculta,

\footnotetext{
${ }^{5}$ A esta concepção filosófica, está relacionada uma concepção historiográfica de uma "história de problemas", tal como apresentada por Ernst Mayr (1998, p. 21). 
tanto quanto era a "tendência a cair" da física aristotélico-medieval. Porém, se havia uma inclinação, na época de Newton, a rejeitar o uso de qualidades ocultas, então se torna, a princípio, incompreensível que este conceito não tenha sido rejeitado.

Todavia, Kuhn (1975) fornece uma explicação bastante plausível: abandonar o conceito de gravidade significava rejeitar a mecânica newtoniana; porém, durante o desenvolvimento da mecânica, os físicos não se sentiam mais capazes de fazer física sem utilizar a estrutura teórica construída por Newton. Diante disso, optou-se pela manutenção do conceito de gravidade.

O interessante aqui, de acordo com o citado autor, é que o conceito não foi mantido por seus méritos intrínsecos, mas em função do mérito da teoria como um todo. Em outras palavras: a sentença acima - "a gravidade foi mantida" - na verdade só possui um sentido dentro do contexto de quem aceitava a mecânica de Newton como uma estrutura teórica.

Para os nossos propósitos, contexto (da forma considerada no parágrafo anterior) pode ser traduzido por redes conceituais, tal como foi proposto por Paul Thagard (1992). Para ele, explicações científicas são construções teóricas que reúnem proposições científicas que se relacionam com as teorias em que figuram sob o critério da coerência (THAGARD, 1992, p. 6465). Assim, não se pode qualificar uma proposição como tendo méritos próprios, na verdade, o mérito de uma proposição é conseguir se estabelecer de forma coerente como um integrante da rede conceitual. Um exemplo trabalhado por Thagard (2007) é o da emergência do conceito de oxigênio ${ }^{6}$.

Sabe-se que este elemento foi descoberto antes de sua assimilação por Lavoisier, e sabe-se também que esta descoberta ocorreu no interior de uma rede conceitual - a da teoria do flogisto; por fim, e o mais importante: esta rede não conseguiu assimilar o conceito de oxigênio de modo coerente. Diferentemente, Lavoisier conseguiu dotar o conceito de um significado dentro de sua própria rede - a da teoria do oxigênio, como a denomina Paul Thagard (2007) e, portanto, forneceu-lhe credenciais teóricas para seu estabelecimento e sua aceitação pela comunidade científica.

Deste modo, quando Lavoisier explicou por que a água não era um elemento, e sim um composto, ele não estabeleceu um fato, na verdade, isto somente se tornou um fato a partir da ambientação conceitual fornecida pela rede conceitual como um todo.

No interior da mesma abordagem, porém com um sotaque relacional ligeiramente diferente, Willard Quine (1960) propôs que as sentenças jogam um jogo de interanimação: uma sentença depende da outra para que a teoria como um todo possua um significado.

Diante disso, mesmo sentenças que consideramos triviais - tais como: "O DNA é composto de fósforo e açúcar" - estão imersas em sua relação com outras sentenças. Por certo, a sentença é importante do ponto de vista empírico, mas ela não é exatamente um passo em direção à sentença que realmente importa: "O DNA é representado molecularmente como uma dupla hélice". E por que não?

\footnotetext{
${ }^{6}$ Quando falamos de conceitos, usamos o mesmo critério de coerência que o acima posto para as proposições. Pois seria possível falar não de conceitos, mas de proposições nas quais os conceitos figuram.
} 
Façamos o seguinte experimento mental (que, na verdade, pode ser reproduzido historiograficamente): adicione todas as informações verdadeiras a respeito do DNA; a soma destas informações não tem como resultado a dupla hélice.

A dupla hélice é mais do que a soma de suas verdades empíricas, por exemplo, ela é uma forma de explicar de que modo outra molécula associada recebe a informação genética contida no interior do DNA. Pois de nada adiantaria sabermos que o DNA é uma dupla hélice se este conhecimento não apontasse para os problemas que circundavam o DNA, dentre eles, o principal seria o de sugerir caminhos para uma explicação químico-física de fenômenos genéticos.

Um dos objetivos de Bruno Latour (2000) em 'A ciência em ação' foi o de apresentar a concepção de que sentenças isoladas, tais como "O DNA é uma dupla hélice", somente podem ser assim consideradas depois que se estabelecem como fatos para a comunidade científica. Porém, o interessante na abordagem de Latour (2000) é que ele apresenta agendas metodológicas para a compreensão tanto de quando quanto de como tais sentenças se estabelecem como descrições de fatos.

O aspecto desconcertante disto tudo é que estas sentenças não se estabelecem - no momento em que se estabelecem - como fatos, por serem descrições de fatos! Em vez disso, tal estabelecimento se dá pela relação da sentença aspirante - "o DNA é uma dupla hélice" - com outras sentenças. Mas isto não é apenas um jogo de sentenças. Para Latour (2000), entra em cena, neste momento, um novo personagem (os veiculadores das sentenças) - os cientistas. Acreditar que é verdade que "o DNA é uma dupla hélice" é menos uma questão de saber se é assim mesmo do que é uma questão de acreditar naquele que profere a sentença. E por que é assim?

Suponha, argumenta Latour (2000, p. 76), que você deseje duvidar da veracidade da sentença, não encontrará pela frente apenas a sentença. Encontrará dezenas (ou centenas ou milhares) de sentenças de alguma forma a ela conectadas; na prática, encontrará dezenas (ou centenas ou milhares) de artigos que a supõem como fato. Em suma, você se deparará com uma estrutura científica organizada e estruturada. Nada impede que você desmonte esta estrutura (Copérnico, Lavoisier e Darwin são exemplos disto, como sabemos), mas é a estrutura que deve ser desmontada, e não a sentença isoladamente.

De acordo com Van Fraassen (1980), quando uma comunidade de investigadores aceita uma determinada teoria científica, ela o faz pelo fato de a teoria ser uma boa explicação para certo conjunto de fenômenos, ou seja: estamos aqui diante de uma explicação epistemológica, a qual cobre a relação entre a teoria (que explica) e a realidade (a ser explicada). O que, segundo ele, nos conduz ao que é chamado de "concepção pragmática da aceitação de teorias" (VAN FRAASSEN, 1980, p. 87). Porém é preciso se perguntar: Por que nós queremos explicar aquele certo tipo de fenômeno?

E isto nos coloca diante de uma abordagem pragmática que, diferente da epistemológica, não se trata apenas da relação entre teoria e realidade, mas leva, igualmente, em consideração o usuário da teoria.

Permanecendo no exemplo que norteará este artigo, percebemos que a comunidade responsável pela aceitação da dupla hélice foi a dos geneticistas. Mas o interessante é que não eram geneticistas os cientistas responsáveis pela produção de evidências empíricas para a sustentação da hipótese de que o DNA era uma dupla hélice (na verdade, eram físicos que 
trabalhavam com cristalografia de raio-X, uma técnica que permitia compreender os aspectos da estrutura física da molécula).

Deste modo, os usuários geneticistas tinham certas perguntas para as quais a dupla hélice fornecia caminhos possíveis para as respostas; e isto teria sido decisivo, de acordo com os historiadores, para a aceitação (em 1953) da dupla hélice (e não teria sido decisivo (em 1953), portanto, se o DNA era realmente uma dupla hélice).

Outras perguntas que poderíamos fazer, a partir da concepção pragmática de Van Fraassen, são as seguintes: Por que, em certos períodos de uma disciplina, são buscados certos tipos de explicação, e não outros? Por que, no exemplo que é tema deste artigo, se procurava por uma estrutura molecular do DNA?

Uma resposta a isto pode ser encontrada em Larry Laudan. Para Laudan (1977), existem, na história da ciência, entidades que ele denomina de "tradições de investigação". Estas tradições de investigação moldam certo domínio de pesquisa e, sobretudo, delimitam o domínio. Deste modo, a busca por um modelo molecular do DNA não ocorreu e, mais do que isso, sequer foi pensada quando da descoberta do DNA em 1859. Tal busca começou a se tornar uma realidade quando o DNA foi assimilado à tradição de investigação da genética molecular, disciplina esta que legitimava este tipo de tratamento molecular do DNA.

Como pôde ser observado, neste segmento de seção (que aqui se finda), procuramos apresentar credenciais filosóficas que nos permitem tratar os conceitos científicos como relacionados $^{7}$ a outros conceitos, teorias, interesses da comunidade científica etc.

\section{Um aspecto da história da dupla hélice em uma concepção relacional}

A história da dupla hélice do DNA, como quase sempre acontece, está repleta de complexidades, idiossincrasias e nuances. Esta história tem sido mapeada pelos historiadores e, atualmente, possuímos um quadro bastante definido dos problemas científicos em que a dupla hélice se inseriu historicamente.

Neste segundo segmento desta seção, nos deteremos em dois momentos fundamentais da construção do modelo: a ênfase na busca pela função genética do DNA e a utilização das regras de Chargaff para a construção do modelo.

Esse recorte é feito em função do fato de que os livros didáticos de biologia, quase sempre, mencionam esses dois aspectos em sua narrativa histórica. Porém, antes de passar ao recorte, apresentaremos rapidamente um extrato da história.

Em 1951, no Laboratório Cavendish, da Universidade de Cambridge, em Cambridge, na Inglaterra, James Watson conhece Francis Crick. Watson tinha conhecimento das pesquisas de Oswald Avery e seus colaboradores, pesquisas estas que, em 1944, sugeriram que o princípio da transformação bacteriana era o DNA (SILVA, 2010, p. 72).

\footnotetext{
${ }^{7}$ Não se sugere, aqui, que esta abordagem seja superior a abordagens não relacionais, apenas se pretende reivindicar tanto a plausibilidade quanto a fecundidade de uma abordagem relacional.
} 
Silva, M. R.; Passos, M. M.; Villas Boas, A.

Essa descoberta foi assimilada pela comunidade como um importante passo na direção de que o agente hereditário fundamental era o DNA (e não as proteínas, como se pensou durante algum tempo).

Próximos de Watson e Crick, no King’s College, em Londres, os físicos Maurice Wilkins e Rosalind Franklin trabalhavam com técnicas de cristalografia de raio-X (difração de raio-X), as quais eram aplicadas ao DNA a fim de se determinar a estrutura da molécula. Para descobrir a estrutura do DNA, Watson e Crick buscam informações empíricas em um seminário do King's (realizado em novembro de 1951), em que Rosalind Franklin apresentou alguns resultados de sua investigação. A partir destes resultados, Watson e Crick constroem um modelo e o apresentam ao grupo do King's. Franklin criticou duramente o modelo e a estrutura foi considerada errada (SILVA, 2010, p. 74).

Ao final de 1952, Watson e Crick são informados de que outro cientista interessado no DNA parecia próximo de apresentar a estrutura do DNA: Linus Pauling. Tendo acesso a um pré-print de Pauling, no final de janeiro de 1953, Watson decide fazer uma visita ao King's para discutir o artigo de Pauling (o qual apresentava um erro grosseiro de química, erro este que tornava inviável o modelo ali proposto). Ele se reúne com Wilkins, que lhe mostra uma cópia de uma evidência empírica produzida por Franklin em 1952. Com base nesta evidência, ele e Crick (depois de algumas tentativas fracassadas) constroem um novo modelo e, em 25 de abril de 1953, publicam, na Nature, o paper contendo o modelo para a estrutura ${ }^{8}$ (SILVA, 2010, p. 75).

\section{Dois aspectos históricos da construção do modelo da dupla hélice}

É um consenso historiográfico que o investimento na busca por uma estrutura molecular do DNA, no final da década de 40 e início da década de 50 do século passado, se devia, também, ao fato de que havia certa expectativa gerada pela possibilidade de esta molécula ocupar um papel central e decisivo para a explicação de fenômenos ligados à genética.

Evidentemente, dada a diversidade dos cientistas envolvidos com as pesquisas sobre DNA neste período mencionado, não se pode afirmar que todos os pesquisadores lidavam com o DNA a partir desta vinculação com a genética, entretanto, pode-se afirmar, com segurança, que a relação entre genética e DNA já estava estabelecida enquanto meta investigativa.

James Watson e Francis Crick trabalhavam a partir desta perspectiva que relacionava, fortemente, DNA e genética (CRICK, 1988, p. 69; MORANGE, 1998, p. 115-116). Para eles, a estrutura do DNA deveria apontar para a função genética da molécula. De posse de alguns dados extraídos de pesquisas alheias ${ }^{9}$, começam a construir modelos para apresentar uma estrutura do DNA. Porém há um detalhe significativo: eles não constroem modelos tendo em vista apenas a apresentação de uma estrutura que seja compatível com os dados, ao invés disso, seus modelos precisam ser explicativos.

\footnotetext{
${ }^{8}$ Fechamos nosso extrato da história.

${ }^{9}$ Não entraremos aqui na polêmica acerca da utilização, por parte de Watson e Crick, dos dados de outros pesquisadores que investigavam o DNA. Sobre isto, ver: Maddox (2002), Pipper (1998) e Sayre (1975).
} 
Explicativos do quê? Da função genética do DNA. Um modelo que não especifique de que modo o DNA faz uma cópia de si mesmo e remete tal cópia para outra molécula associada não é, na concepção de Crick e Watson, um modelo útil. Deste modo, não basta apresentar uma estrutura. A estrutura precisa apontar a função (SILVA, 2010, p. 76).

Isto pode ser confirmado quando nos deparamos com uma carta que Watson escreve a um geneticista bastante interessado nas implicações do DNA para a genética, Max Delbruck. $\mathrm{Na}$ época em que Watson escreve a carta, Linus Pauling havia proposto uma estrutura para o DNA. E, na carta, Watson critica a estrutura de Pauling não por seus defeitos internos, mas por não especificar como o DNA se replicaria. Watson anuncia a Delbruck que ele e Crick estão enviando, à revista Nature, um artigo com o modelo da dupla hélice. Porém, eles não sabem se o modelo é sustentado por evidências empíricas, mas, se for sustentado, ele abrirá o caminho para se compreender a replicação do DNA. Ao final da carta, ele declara que prefere o tipo de modelo que ele e Crick estão construindo, pois, mesmo que o modelo de Pauling fosse correto, ele não diria quase nada sobre a reprodução do DNA (OLBY, 1974, p. 416).

A partir deste momento, adentramos ao segundo ponto importante (neste artigo) da construção da dupla hélice ${ }^{10}$ : os dados empíricos de Erwin Chargaff.

Chargaff (apud SILVA, 2010, p. 73) descobriu experimentalmente que as bases que integram o DNA possuem certa regularidade relacional. Assim, para cada quantidade de adenina, há uma quantidade quase igual de timina; e para cada quantidade de citosina, há uma quantidade quase igual de guanina. Isto foi resumido na seguinte sentença, chamada "Regra de Proporção de Chargaff": AT = 1, CG = 1 .

Esta foi uma descoberta empírica fundamental para a pesquisa sobre DNA, porém ela precisava ser assimilada. Watson e Crick efetuam tal assimilação, e usam as regras de proporção como um princípio empírico para postularem o que denominaram de "pareamento das bases". O pareamento é a maneira pela qual se explica o modo como as bases vão sendo produzidas a partir de outras bases. Ora, esta foi uma informação empírica fundamental para Watson e Crick, mas que só se tornou significativa no interior do modelo da dupla hélice. Não que as proporções de Chargaff, em si, não possuíssem um significado empírico, porém tais proporções se tornaram explicadas pelo pareamento, e este conceito - pareamento - não foi uma descoberta, mas uma construção teórica de Watson e Crick (CRICK, 1988, p. 55-56; ELKIN, 2003; WATSON, 1997, p. 151; WILKINS, 2003, p. 154; p. 221).

De posse destes dois aspectos históricos - a discussão sobre a função genética do DNA e as regras de Chargaff - podemos, agora, extrair uma pequena história articulada a partir de um ponto de vista relacional.

\section{A dupla hélice em um enfoque relacional}

A descoberta de Chargaff foi, como já frisamos, fundamental para o modelo da dupla hélice. Porém, para a dupla hélice, ela não foi decisiva em si mesma, senão que dependeu de sua utilização direcionada por parte de Watson e Crick.

${ }^{10}$ Por isso, no título deste segmento de seção, anunciamos ‘dois aspectos históricos'. 
Silva, M. R.; Passos, M. M.; Villas Boas, A.

Seria um exagero dizer que as descobertas de Chargaff só receberam um significado por causa de sua utilização por Watson e Crick, porém, é inegável que tal utilização criativa foi tão fundamental quanto os próprios dados ${ }^{11}$. Isso posto, o interessante é que tal utilização não poderia ser produzida por qualquer pesquisador que estivesse trabalhando, de uma forma ou outra, com DNA. Ao invés disso, esta utilização dependia, fundamentalmente, de uma concepção prévia a respeito da importância da função genética do DNA (e, quem sabe, de outras concepções prévias relacionadas), e, evidentemente, da compreensão da percepção da importância, para alcançar uma explicação da função genética do DNA, dos dados de Chargaff. Vale lembrar que outro grande cientista envolvido nesta discussão - Linus Pauling - reconheceu que foi incapaz de compreender a importância genética dos dados de Chargaff (PAULING, 1974, p. 771). Outro envolvido - Maurice Wilkins - declara ter percebido a importância, mas foi incapaz de dar o passo dado por Watson e Crick (WILKINS, 2003, p. 221) ${ }^{12}$.

Deste modo, as sentenças de Chargaff ( $\mathrm{AT}=1, \mathrm{CG}=1)$ não estão isoladas, para Watson e Crick. Elas compõem um corpo de sentenças relacionadas, por exemplo: é fundamental, quando da construção de uma estrutura para o DNA, que esta estrutura aponte caminhos para que se possam explorar as consequências genéticas desta estrutura. Esta última, por sua vez, estaria na base de outras sentenças e, assim, sucessivamente. Além disso, desejar explorar as consequências genéticas desta estrutura é uma decisão, e não um fato empírico.

\section{A história da dupla hélice nos livros didáticos}

Apresentaremos, agora, uma descrição da história da dupla hélice em alguns livros didáticos brasileiros de biologia do Ensino Médio. Faremos esta apresentação na forma de um quadro, em que constarão os itens históricos encontrados nos livros que tenham relação com a dupla hélice do DNA.

A seleção dos livros que constituem o acervo para este movimento investigativo ancora-se em documentos do Ministério da Educação e Cultura (MEC), do Programa Nacional do Livro Didático (PNLD), voltado à distribuição de obras didáticas aos estudantes da rede pública de ensino brasileira (FUNDO NACIONAL DE DESENVOLVIMENTO DA EDUCAÇÃO, 2012a).

Um programa que se iniciou no ano de 1929 e, a partir do ano de 2004, foi implantada uma nova etapa do PNLD - intitulada Programa Nacional do Livro para o Ensino Médio (PNLEM) - que previa a universalização de livros didáticos para os alunos do Ensino Médio público de todo o País.

Foi com base na seguinte chamada que chegamos à relação de livros que passaram a constituir nosso corpus ${ }^{13}$ de pesquisa.

\footnotetext{
${ }^{11}$ Não é objetivo deste artigo avaliar, comparativamente, a descoberta de Chargaff e a utilização de Watson e Crick desta descoberta.

${ }^{12}$ De acordo com Crick (1974, p. 768), Rosalind Franklin também não tinha percebido o significado do pareamento das bases.

${ }^{13} \mathrm{O}$ conjunto dos documentos tidos em conta para serem submetidos aos procedimentos analíticos (BARDIN, 2004, p. 90).
} 
Já está disponível no sítio do Fundo Nacional de Desenvolvimento da Educação (www.fnde.gov.br) o catálogo do Programa Nacional do Livro para o Ensino Médio (PNLEM 2009). A publicação contém um resumo de todos os livros didáticos que estão disponíveis para escolha dos professores das escolas de ensino médio da rede pública em todo o País. A escolha só ocorrerá em junho, mas os docentes já podem estudar o catálogo para fazer a melhor opção dos livros que serão usados pelos estudantes e professores a partir do início do ano letivo de 2009.

O catálogo resulta de um criterioso processo de seleção das obras inscritas pelas editoras e apresenta uma resenha e a estrutura dos livros, faz uma análise crítica dos seus aspectos conceituais, metodológicos e éticos e sugere caminhos para práticas pedagógicas. (FERRAZ, 2008)

Neste documento disponibilizado pelo Ministério da Educação (FUNDO NACIONAL DE DESENVOLVIMENTO DA EDUCAÇÃO, 2012b), observa-se a relação com os nove títulos da disciplina de biologia que podem ser escolhidos pelos professores que atuam no Ensino Médio. Desses livros - cinco em versão volume único e quatro na forma de coleção com três volumes - desenvolvemos um trabalho de busca em sete deles. Alguns dos resultados obtidos e que deram norte a diversas de nossas reflexões estão apresentados de forma resumida no Quadro 1.

Podemos perceber que a história da dupla hélice aparece com frequência nos livros didáticos. Mais do que isso: não localizamos quaisquer erros históricos nas narrativas. A princípio, em um movimento avaliativo das propostas, podemos nos dar por satisfeitos com a apresentação deste episódio nos livros. Por conseguinte, coloca-se a pergunta: Satisfeitos a partir de que ponto de vista?

Considerando que "ponto de vista" deve ser traduzido por "tipo de história", a pergunta precisa ser reelaborada: Satisfeitos a partir de que tipo de história? Evidentemente, a resposta deve variar à medida que varia o tipo de história que se deseja adotar.

Como, nesta investigação, assumimos, para orientar nossas análises, um tipo de história denominado história de problemas - que se coloca como solidária ao enfoque relacional apresentado anteriormente -, veremos, então, em que medida a história dos livros satisfaz um pesquisador (avaliador de livros didáticos) que tem por base esse conceito.

Em continuidade ao que foi estruturado anteriormente, na próxima seção, discutiremos algumas implicações das narrativas dos livros e apresentaremos uma objeção à concepção filosófica geral aqui descrita. Por fim, concluiremos, encaminhando uma proposta que acomoda as expectativas dos que idealizam os livros didáticos e daqueles que são representantes da pesquisa na área.

\section{Em discussão: a história da dupla hélice inserida nos livros didáticos}

Vimos então que, do ponto de vista histórico, não há nada de errado com os livros didáticos em relação à dupla hélice do DNA. Não existe erro histórico informativo, por exemplo. Mas poderia ser argumentado que existem omissões - ou faltam informações. Neste caso, 
Silva, M. R.; Passos, M. M.; Villas Boas, A.

Quadro 1. Relação dos livros e resumo de seus conteúdos históricos referentes à dupla hélice do DNA

\begin{tabular}{|c|c|}
\hline $\begin{array}{l}\text { Relação dos livros indicados } \\
\text { no catálogo de Biologia } \\
\text { do PNLEM/2009 }\end{array}$ & Conteúdo histórico \\
\hline $\begin{array}{l}\text { Biologia: volume único } \\
\text { Sérgio Linhares e Fernando } \\
\text { Gewandsznajder. 1a edição. } \\
\text { Editora Ática, } 2005 \text {. }\end{array}$ & $\begin{array}{l}\text { - Autoria da apresentação da dupla hélice; } \\
\text { - Autoria da descoberta das proporções das bases. }\end{array}$ \\
\hline $\begin{array}{l}\text { Biologia: volume único } \\
\text { José Arnaldo Favaretto e } \\
\text { Clarinda Mercadante. } 1^{\mathrm{a}} \text { edição. } \\
\text { Editora Moderna, } 2005 .\end{array}$ & $\begin{array}{l}\text { - Autoria da apresentação da dupla hélice; } \\
\text { - Autoria da descoberta das proporções das bases; } \\
\text { - Menciona os trabalhos de difração de raio-X utilizados por Watson e Crick; } \\
\text { - Data da descoberta do DNA como material genético apenas das bactérias. }\end{array}$ \\
\hline $\begin{array}{l}\text { Biologia: volume único } \\
\text { Augusto Adolfo, Marcos } \\
\text { Crozetta e Samuel Lago. } 2^{\mathrm{a}} \\
\text { edição. Editora IBEP, } 2005 .\end{array}$ & $\begin{array}{l}\text { - Data da descoberta do DNA; } \\
\text { - Data da descoberta do DNA como material genético; } \\
\text { - Data e autoria da apresentação da dupla hélice; } \\
\text { - Autoria da descoberta das proporções das bases; } \\
\text { - Autoria dos trabalhos de difração de raio-X utilizados por Watson e Crick. }\end{array}$ \\
\hline $\begin{array}{l}\text { Biologia: volumes } 1,2 \text { e } 3 \\
\text { César da Silva Júnior e Sezar } \\
\text { Sasson. } 8^{a} \text { edição. Editora } \\
\text { Saraiva, } 2005 .\end{array}$ & $\begin{array}{l}\text { - Descrição sintética da descoberta do DNA; } \\
\text { - Data e autoria da apresentação da dupla hélice; } \\
\text { - Relato da descoberta do DNA como material genético. }\end{array}$ \\
\hline $\begin{array}{l}\text { Biologia: volumes } 1,2 \text { e } 3 \\
\text { José Mariano Amabis e Gilberto } \\
\text { Rodrigues Martho. } 2^{\mathrm{a}} \text { edição. } \\
\text { Editora Moderna, } 2005 .\end{array}$ & $\begin{array}{l}\text { - Descrição da descoberta do DNA; } \\
\text { - Autoria da apresentação da dupla hélice; } \\
\text { - Autoria da descoberta das proporções das bases; } \\
\text { - Descrição detalhada da descoberta do DNA como material genético, mas } \\
\text { com o cuidado de não apresentar os descobridores como sustentando a tese } \\
\text { de que o DNA seria o material genético das bactérias (e mostram, em } \\
\text { seguida, que esta foi uma possibilidade testada por outros cientistas); } \\
\text { - Menciona os trabalhos de difração de raio-X utilizados por Watson e Crick; } \\
\text { - Sugestão de que Watson e Crick montaram um quebra-cabeça a partir das } \\
\text { informaçães disponíveis; } \\
\text { - Afirmação de que o modelo foi aceito imediatamente pela comunidade } \\
\text { científica; } \\
\text { - Descrição detalhada da descoberta do DNA como material genético, mas } \\
\text { com o cuidado de não apresentar os descobridores como sustentando a tese } \\
\text { de que o DNA seria o material genético das bactérias, mas apenas das } \\
\text { bactérias usadas nos seus experimentos }{ }^{15} ; \\
\text { - Menciona os trabalhos de difração de raio-X (mas não deixa claro que } \\
\text { Watson e Crick não participaram deste trabalho). }\end{array}$ \\
\hline $\begin{array}{l}\text { Biologia: volumes } 1,2 \text { e } 3 \\
\text { Wilson Roberto Paulino. } 1^{\text {a }} \\
\text { edição. Editora Ática, } 2005 .\end{array}$ & $\begin{array}{l}\text { - Descrição da descoberta do DNA; } \\
\text { - Autoria da descoberta das proporções das bases; } \\
\text { - Data e autoria da apresentação da dupla hélice. }\end{array}$ \\
\hline $\begin{array}{l}\text { Biologia: volume único } \\
\text { Sônia Lopes e Sergio Rosso. } 1^{\mathrm{a}} \\
\text { edição. Editora Saraiva, 2005. }\end{array}$ & $\begin{array}{l}\text { - Descrição da descoberta do DNA; } \\
\text { - Data e autoria da descoberta do DNA como material genético; } \\
\text { - Data e autoria da apresentação da dupla hélice. }\end{array}$ \\
\hline
\end{tabular}

${ }^{14}$ Exceto os seguintes livros, aos quais não tivemos acesso: LAURENCE, J. Biologia: volume único. São Paulo: Nova Geração, 2005; FROTA-PESSOA, O. Biologia: volumes 1, 2 e 3. São Paulo: Scipione, 2005.

${ }^{15}$ No caso desta descrição, justificamos a repetição - em parte - com o que foi apresentado anteriormente nesta célula, pelo fato de que este conteúdo é abordado em mais de um volume (são três ao todo) com algumas diferenças argumentativas.

Fonte: elaborado pelos autores. 
a acusação teria de ser ampliada e alcançaria, inclusive, os livros clássicos de história da dupla hélice, uma vez que, virtualmente, todos omitem um ou outro aspecto devido a orientações metodológico-historiográficas previamente traçadas ${ }^{16}$.

Sendo assim, qual é o problema com os livros didáticos a respeito da história correta por eles narrada sobre a dupla hélice? Ora, também não se faz aqui nenhum juízo de valor a respeito do conteúdo histórico que os livros veiculam. Em outros termos: não se identifica sequer que exista um problema com a veracidade da história da dupla hélice narrada nos livros. $\mathrm{Na}$ verdade, o que se pretende verificar é a imagem de ciência que pode ser passada ao leitor a partir das narrativas e das informações veiculadas.

Quando se enuncia uma sentença verdadeira, tal como "o DNA é uma dupla hélice", e quando isto é feito de modo que esta sentença apareça isoladamente, é possível que certa concepção de ciências seja veiculada. Para compreender este ponto, pedimos ao leitor que examine as duas sentenças a seguir:

- O DNA é uma dupla hélice. (sentença A)

- Foi descoberto por Watson e Crick em 1953 que o DNA é uma dupla hélice. (sentença B)

A sentença (A) é uma informação científica, atemporal e impessoal. Não especifica nada em termos de sua história e de sua gênese. A sentença (B) incorpora a sentença (A) no aspecto informativo - continuamos sabendo que o DNA é uma dupla hélice -, mas acrescenta as informações históricas de que (A) se deve à descoberta de dois cientistas e de que isto ocorreu em um ano determinado. Diante de (A) e (B), quais seriam as reações possíveis dos leitores?

Diante de (A), o leitor prossegue em seus estudos sobre a dupla hélice; provavelmente, em seguida, irá aprender algo sobre a constituição química da molécula. Todavia, o importante aqui é o seguinte: diante de (A), que 'direito' tem o leitor de exigir informações históricas ou articulações historiográficas que tornem a dupla hélice compreensível a partir de sua história?

Se usarmos o termo 'direito' com alguma propriedade, a resposta é: nenhum direito. O autor do livro didático ofereceu (A) como uma informação científica que, certamente, será ampliada e relacionada a outras informações, e o final pretendido, certamente, é o domínio, por parte do leitor, de alguma unidade de conhecimento.

Porém, o autor não ofereceu respaldo para o questionamento a respeito da história que circunda (A). E, então, é neste sentido que o uso da palavra 'direito', anteriormente, foi restrito. E podemos também acrescentar que, até aqui, nenhuma concepção de ciência foi constituída.

Vejamos, agora, o que pode fazer este leitor diante de (B). Por meio de (B), ele foi informado de que dois cientistas descobriram que o DNA é uma dupla hélice, e, além disso, que esta descoberta ocorreu em certo ano. Ao contrário de (A), (B) pode suscitar, no leitor,

\footnotetext{
${ }^{16}$ Cabe destacar que, neste artigo, omitimos, por questão de espaço e de objetivo, quase toda a história deste episódio, ficando apenas com os elementos indispensáveis para a discussão aqui proposta.
} 
Silva, M. R.; Passos, M. M.; Villas Boas, A.

questionamentos de natureza histórica. Ele pode perguntar, com pleno direito, por exemplo: Por que foram Crick e Watson, e não outros? Ele pode ainda questionar: Por que foi em 1953, e não em 1954? Paramos por aqui, pois as possibilidades abertas por (B) são inúmeras.

Diante do que se coloca a respeito do posicionamento do leitor, há também algumas reflexões a respeito do posicionamento do autor ${ }^{17}$ (do livro didático) que precisam ser consideradas. Mediante as questões históricas evidenciadas, podemos inferir: a partir de (A), ele (autor) não tem a obrigação de oferecer qualquer comentário histórico; entretanto, se partirmos de (B), a narrativa pode ser direcionada para além da informação histórica contida na própria (B).

Caso se opte por uma história de problemas, (B) é claramente insatisfatória. No entanto, vamos, neste momento, transformar (B) em uma sentença real que aparece nos livros didáticos. Em 'Biologia das populações', Amabis e Martho (2005) afirmam que Watson e Crick montaram um quebra-cabeça a partir das informações disponíveis. Chamaremos esta afirmação de sentença $(\mathrm{Q})$.

Enquanto informação geral, a sentença $(\mathrm{Q})$ aponta para um caminho interessante do ponto de vista historiográfico e, além disso, confere legitimidade à tese amplamente aceita de que a construção do modelo foi um trabalho coletivo (ANDRADE; CALDEIRA, 2009, p. 151; SCHEID; FERRARI; DELIZOICOV, 2005). Até aqui, de um ponto de vista geral, a proposta dos autores parece indicar um caminho na direção de uma história de problemas.

Porém, alguém poderia levar a sério a metáfora do quebra-cabeça e se questionar: Sendo um quebra-cabeça, podemos concluir, então, que havia peças prontas que, relacionadas umas com as outras, formavam um quadro coerente (seja ele como for) - a figura a ser montada? E é exatamente aqui que a metáfora pode começar a se revelar deficiente.

Suponha que três pessoas se dirijam a uma loja e comprem o mesmo quebra-cabeça. As três partilham tanto as peças quanto - e isto é decisivo aqui para a argumentação - o objetivo do jogo: montar certa figura. É exatamente isto, que não ocorria com a pesquisa com DNA. Havia, ali, não um, mas três quebra-cabeças a serem montados.

Rosalind Franklin desejava construir uma estrutura para o DNA - tivesse a forma que tivesse - que fosse empiricamente impecável de acordo com os princípios teóricos da cristalografia.

Linus Pauling desejava construir uma estrutura para o DNA - tivesse a forma que tivesse - que atendesse a seu plano metodológico geral de construir modelos que satisfizessem as leis da química.

Watson e Crick desejavam (como já vimos) construir uma estrutura para o DNA que apontasse um caminho para que se compreendesse a função genética do DNA.

\footnotetext{
${ }^{17}$ Utilizamos, aqui, o termo “autor" por razões de economia semântica. Na verdade, quando falamos do autor do livro didático, queremos nos referir ao sistema do livro didático como um todo - sistema este que envolve a editora, o próprio autor e os usuários do livro (docentes e discentes); e, no caso de livros distribuídos pelo Ministério de Educação (MEC), têm-se as exigências do próprio edital de inscrição, avaliação e qualificação desses livros.
} 
Três objetivos diferentes, três quebra-cabeças diferentes. E, se são quebra-cabeças diferentes, possuem peças diferentes. Por exemplo: a peça "regras" para Chargaff é, de fato, uma peça no quebra-cabeça de Watson e Crick, mas não é uma peça para Rosalind Franklin e para Linus Pauling, embora nenhum dos dois últimos ignorasse a existência das regras de Chargaff. E é aqui que uma concepção relacional começa a se tornar atrativa.

A rede teórica de Watson e Crick possui um elemento (ou peça, para manter a metáfora do quebra-cabeça) que está ausente nas redes de Rosalind Franklin e de Linus Pauling: o objetivo de, por meio da estrutura, apontar pistas para a compreensão da função do DNA.

Assumido este elemento, se torna então compreensível a utilização que Watson e Crick fizeram das proporções, a ponto de terem transformado, essas proporções, em pareamento. Deste modo, a sentença (Q) deveria, caso se optasse por uma história de problemas, ser reescrita em uma notação relacional (sentença QR), podendo ser assim apresentada:

- (QR): Watson e Crick montaram um quebra-cabeça cuja figura (o objetivo) deveria apresentar uma estrutura que fosse um ponto de partida para uma explicação da função genética do DNA.

Note-se que estamos agora operando em uma plataforma relacional. Os elementos não aparecem mais justapostos e isolados (como na sentença $(\mathrm{Q})$ ), mas no interior de uma rede. A estrutura se relaciona com a função; a busca pela função coloca certas restrições à estrutura; as proporções de Chargaff são compatíveis com o objetivo acima estipulado etc.

E o que se torna interessante nesta proposta é que esta plataforma relacional aponta concepções de ciências: cientistas possuem certos objetivos; nem sempre os objetivos são compartilhados por todos os que trabalham em problemas próximos; colocar-se um objetivo, e não outro, pode ajudar a explicar o sucesso de uns etc.

Mediante a construção argumentativa apresentada até o momento, um leitor deste artigo poderia dar razão aos autores do artigo. Todavia, ele poderia nos apresentar uma dificuldade. Ainda que, aceitando a plausibilidade da argumentação, objetar que a argumentação proposta faz uso de mais elementos históricos dos que estão disponíveis nos livros didáticos. A partir dessa colocação, apresentamos, a seguir, nossas considerações, com o intuito de solucionar este impasse.

\section{Conclusão}

Considerando que uma quantidade expressiva dos livros didáticos examinados traz informações tanto da relação do DNA com a genética, quanto das proporções de Chargaff, podemos, com segurança, afirmar que, em nossa argumentação a favor de uma abordagem relacional, nada foi acrescentado à história da dupla hélice nos livros, em termos de elementos históricos constituintes. Foi acrescentado, apenas, um modo de utilizar e dispor tais elementos. Este modo se justifica (embora, com tal justificação, não se pretenda sequer sugerir que este modo seja superior a outros) do ponto de vista filosófico, do ponto de vista histórico e, por fim, do ponto de vista da constituição de uma concepção de ciências. 
Silva, M. R.; Passos, M. M.; Villas Boas, A.

É importante ressaltar que este modo relacional de dispor as informações históricas aponta caminhos para um desenvolvimento das sentenças tipo (B), que proliferam nos livros didáticos. Desta forma, em uma concepção relacional, sentenças tipo (B) se legitimam e não geram duplicatas historiográficas que só poderão ser saldadas com consultas a livros de história da ciência. Assim, uma sentença tipo (B) - tal como "Watson e Crick utilizaram os dados de Chargaff" - pode ser facilmente explicada com o acréscimo de outras duas: i) uma que apresente o objetivo de Watson e Crick; ii) uma outra que apresente que, dado este objetivo, se explica o porquê da utilização.

Desta forma, podemos concluir que uma concepção de ciências baseada em uma abordagem relacional, embora possa ser considerada uma demanda filosófico-historiográfica, já possui condições de viabilidade nos livros didáticos, visto que, nestes, já estão presentes os elementos históricos indispensáveis para a apresentação de uma história de problemas.

Sendo assim, embora consideremos legítimo que uma das tarefas atuais dos pesquisadores de ensino de ciências seja a de analisar criticamente - do ponto de vista historiográfico - o livro didático, por meio da verificação do tipo de história ali presente, entende-se, igualmente, que é possível efetuar tal análise crítica tendo como ponto de partida as afirmações históricas dos próprios livros e, com isso, buscarmos compreender as possibilidades pedagógicas historiográficas das narrativas inseridas nestes livros didáticos.

O que se observa é que essas propostas já trazem suas potencialidades; elas encontram-se presentes nas sentenças que compõem os textos dos manuais, todavia, poderiam ser elaboradas, discutidas, refletidas em um processo de diálogo entre o autor - com seu desafio de planejar e desenvolver sequências de aprendizagem, inerentes aos procedimentos didáticos - e o pesquisador - com suas competências teórico-interpretativas.

Diante da proposição deste movimento, espera-se ampliar os canais de diálogo entre a comunidade dos pesquisadores da área de ensino de ciências e os autores dos livros didáticos.

\section{Referências}

ADOLFO, A.; CROZETTTA, M.; LAGO, S. Biologia: volume único. 2. ed. São Paulo: IBEP, 2005.

AMABIS, J. M.; MARTHO, G. R. Biologia. 2. ed. São Paulo: Moderna, 2005. 3 v.

ANDRADE, M.; CALDEIRA, A. O modelo de DNA e a biologia molecular: inserção histórica para o ensino de biologia. Filosofia e História da Biologia, São Paulo, v. 4, p. 139-165, 2009.

BARDIN, L. Análise de conteúdo. 3. ed. Lisboa: Edições 70, 2004.

CAMPOS, A. F.; LIMA, E. N. de. Ciclo do nitrogênio: abordagem em livros didáticos de ciências do ensino fundamental. Investigações em Ensino de Ciências, Porto Alegre, v. 13, n. 1, p. 35-44, 2008. 
A história da dupla hélice do DNA ...

CARNEIRO, M. H. da S.; GASTAL, M. L. História e filosofia das ciências no ensino de biologia. Ciência \& Educação, Bauru, v. 11, n. 1, p. 33-39, 2005.

CRICK, F. The double helix: a personal view. Nature, London, n. 248, p. 766-769, 26 Apr. 1974.

What mad pursuit: a personal view of scientific discovery. New York: Basic Books, 1988.

ELKIN, L. O. Rosalind Franklin and the double helix. Physics Today, New York, v. 56, n. 3, p. 42-48, Mar. 2003.

FAVARETTO, J. A.; MERCADANTE, C. Biologia: volume único. São Paulo: Moderna, 2005.

FERRAZ, L. Guia do livro didático do ensino médio já está na internet. In: FUNDO NACIONAL DE DESENVOLVIMENTO DA EDUCAÇÃO. Sala de imprensa: notícias. Brasília: FNDE, 2008. Disponível em: < http://www.fnde.gov.br/fnde/sala-de-imprensa/ noticias/item/707-guia-do-livro-didático-do-ensino-médio-já-está-na-internet>. Acesso em: 19 dez. 2010.

FUNDO NACIONAL DE DESENVOLVIMENTO DA EDUCAÇÃO. PNLD: apresentação. Brasília, 2012a. Disponível em: < http://www.fnde.gov.br/programas/livrodidatico/livro-didatico-apresentacao >. Acesso em: 07 ago. 2013.

Guia PNLEM 2009. Brasília: FNDE, 2012b. Disponível em: <http://

www.fnde.gov.br/programas/livro-didatico/guia-do-livro/item/3812-guia-pnld-2009ensino-médio>. Acesso em: 07 ago. 2013.

KUHN, T. A estrutura das revoluções científicas. 3. ed. São Paulo: Perspectiva, 1975.

LATOUR, B. A ciência em ação. São Paulo: Ed. da Unesp, 2000.

LAUDAN, L. Progress and its problems. London: Routledge, 1977.

LINHARES, S.; GEWANDSZNAJDER, F. Biologia: volume único. São Paulo: Ática, 2005. LOPES, S.; ROSSO, S. Biologia: volume único. São Paulo: Saraiva, 2005.

MADDOX, B. Rosalind Franklin: the dark lady of DNA. New York: Harper Collins, 2002. MARPICA, N. S.; LOGAREZZI, A. J. M. Um panorama das pesquisas sobre livro didático e Educação Ambiental. Ciência \& Educação, Bauru, v. 16, n. 1, p. 115-130, 2010.

MAYR, E. O desenvolvimento do pensamento biológico. Brasília: UnB, 1998.

MEGID NETO, J.; FRACALANZA, H. O livro didático de ciências: problemas e soluções. Ciência \& Educação, Bauru, v. 9, n. 2, p. 147-157, 2003.

MELO, J. R.; CARMO, E. M. Investigações sobre o ensino de genética e biologia molecular no ensino médio brasileiro: reflexões sobre as publicações científicas. Ciência \& Educação, Bauru, v. 15, n. 3, p. 593-611, 2009. 
Silva, M. R.; Passos, M. M.; Villas Boas, A.

MORANGE, M. A history of molecular biology. Cambridge: Harvard University Press, 1998.

OLBY, R. The path to the double helix. London: MacMillan, 1974.

PAULING, L. Molecular basis of biological specificity. Nature, London, n. 248, p. 769-771, 1974.

PAULINO, W. R. Biologia. São Paulo: Ática, 2005. 3 v.

PIPPER, A. Light on a dark lady. Trends in Biochemical Sciences, Amsterdam, v. 23, p. 151-54, 1998.

QUINE, W. Word and object. Cambridge: MIT Press, 1960.

SANDRIN, M. de F. N.; PUORTO, G.; NARDI, R. Serpentes e acidentes ofídicos: um estudo sobre erros conceituais em livros didáticos. Investigações em Ensino de Ciências, Porto Alegre, v. 10, n. 3, p. 281-298, 2005.

SANTOS, J. C. dos et al. Análise comparativa do conteúdo filo mollusca em livro didático e apostilas do ensino médio de Cascavel, Paraná. Ciência \& Educação, Bauru, v. 13, n. 3, p. 311-322, 2007.

SAYRE, A. Rosalind Franklin and DNA. New York: W. W. Norton, 1975.

SCHEID, N.; FERRARI, N.; DELIZOICOV, D. A construção coletiva do conhecimento científico sobre a estrutura do DNA. Ciência \& Educação, Bauru, v. 11, n. 2, p. 223-233, 2005.

SILVA, M. As controvérsias a respeito da participação de Rosalind Franklin na construção do modelo da dupla hélice. Scientiae Studia, São Paulo, v. 8, n. 1, p. 69-92, 2010.

SILVA JÚNIOR, C. da; SASSON, S. Biologia. 8. ed. São Paulo: Saraiva, 2005. 3 v.

THAGARD, P. A estrutura conceitual da revolução química. Princípios, Natal, v. 14, n. 22, p. 265-303, 2007.

Conceptual revolutions. Princeton: Princeton University Press, 1992.

VAN FRAASSEN, B. The scientific image. Oxford: Clarendon Press, 1980.

WATSON, J. The double helix. London: Weidenfeld \& Nicholson, 1997.

WILKINS, M. The third man of the double helix. Oxford: Oxford University Press, 2003.

XAVIER, M. C. F.; FREIRE, A. de S.; MORAES, M. O. A nova (moderna) biologia e a genética nos livros didáticos de biologia no ensino médio. Ciência \& Educação, Bauru, v. 12, n. 3, p. 275-289, 2006.

Artigo recebido em 23/10/12. Aceito em 09/03/13.

616

Ciênc. Educ., Bauru, v. 19, n. 3, p. 599-616, 2013 